\title{
The construction of e-commerce credit system
}

\author{
Liu Ke \\ School of Economics and Management \\ Zhengzhou University of Light Industry \\ Zhengzhou, China \\ e-mail: liuke_liu@163.com
}

\author{
Tang Song \\ School of Economics and Management \\ Zhengzhou University of Light Industry \\ Zhengzhou, China \\ e-mail: tangsong_77@163.com
}

\begin{abstract}
In the thesis the author analyzed the lack of credit in the course of the construction of China's e-commerce, the main bottleneck in its sound development, explored its causes, and on which basis, puts forward some constructive measures and suggestions to improve the credit in the construction of China's e-commerce.
\end{abstract}

Keywords-electronic commerce; credit system; construction

In recent years, with the popularity of the Internet, electronic business in China has been rapidly developed. As an important part of China's strategic emerging industries and modern methods of distribution, electronic commerce plays an important role in meeting and enhancing consumers' demands, improving the industry and the institutionalization of the resources, and transforming economic development mode. However, in such a rapid development of electronic commerce, the problem with the credibility came into being and has begun to restrict the development of electronic commerce. It is an urgent need to analyze the integrity issues of our country's electronic commerce and explore the construction of electronic commerce credit system for the development of electronic commerce in China.

\section{THE PROBLEMS OF ELECTRONIC COMMERCE CREDIT}

Electronic commerce is a whole electronic, digitalized, and networked business process achieved by computer technology, network technology and the remote communications technology. With all activities of businesses and consumers taking place in the virtual network, some integrity problems are possible.

\section{A. Internet Fraud}

Internet Fraud is a behavior that diddles large amount of property for the purpose of illegal possession by faking or concealing the truth in the virtual world of the Internet. It is the most typical form of lack of credibility. The fact that there is a lack of information symmetry in the mutual knowledge between electronic commerce operators and online shoppers are very easily misused by illegal electronic commerce businesses, resulting in the fraudulent operations of electronic business operators. As the consumers can get little or no relevant information in the transaction process, electronic business operators use this to cheat the customers for illegal interests with various methods. Now the Internet fraud is becoming increasingly cleverer and in more concealed forms, and thus very difficult for the customers to guard against.

\section{B. Inferior quality of the goods}

In online shopping, the shoppers obtain the information about commodities by browsing the goods in pictures, in text and from other buyers' evaluations. Unlike the purchase in real life, online shoppers can not have a direct view of the products. So it is possible that the commodities they have bought are totally different from the knowledge they have acquired. This can seriously affect the shopping experience. The e-commerce operators often take advantages of this feature of online shopping. The goods are advertised as of high quality, but are actually defective or adulterated. In some C2C forms of electrical business, the same commodity can vary from a dozens of Yuan or even thousands of Yuan in their prices. These goods are uneven in their products, making the shopping experience not so pleasant. So many consumers are very cautious about online shopping, and some even completely give up online shopping to avoid possible losses and turn to the traditional shopping mode.

\section{Lack of Credit in After-sales Service}

When the online transaction is carried out, consumers cannot receive proper after-sales service as they can in reallife purchase if there are problems with the products. The goods purchased often cannot get after-sales service. For instance, they may have a hard time in receiving after-sales service and exchanging or returning goods can be both timeand energy-consuming. When there are quality problems with the purchased goods, due to the fact that the business operators cannot offer proper after-sales service, many consumers tend to give up their rights, and the purchased goods lose their value of use. This not only results in a waste, but also seriously affects consumers' shopping experience. So network trade becomes "one-time trade" for some consumers. A survey shows $16.59 \%$ of the consumers can't get after-sale warranty, $19.91 \%$ find that the goods shipped by sellers are of poor quality, $17.54 \%$ think the shipment is not timely, $18.01 \%$ receive fake good, $12.8 \%$ say claims of losses are difficult, $4.74 \%$ think otherwise, and only $10.43 \%$ say they are satisfied with the commodity. The data demonstrates that serious credit problems exist in the electronic commerce service. 


\section{Personal information leakage}

As the e-commerce is completed in the Internet, many unsafe factors in the Internet will affect e-commerce transaction privacy, such as hackers or Trojan virus, etc. The online buyers' personal information is at the risk of being stolen and misused. The cost of offenders to get users' personal information is very low. For example, some people in Taobao issue auction of goods at a very cheap price and cancel the delivery of goods in various pretexts after obtaining user's personal information. By selling the consumers' personal information, they can obtain high income. This intensifies the leakage of personal information in e-commerce. Although it is an infringement of privacy to use the private information of the online business operators and consumers without their approval, many illegal ecommerce business operators violate the privacy of the consumers by selling some private data of the consumers to other businessmen.

\section{CAUSES OF LACK OF CREDIBILITY IN E-COMMERCE}

\section{A. Imperfect laws and regulations}

Although the electronic commerce in our country enjoys rapid development, there has been no relevant laws for the electronic commerce to restrain and regulate the behaviors of both the two parties involved in the electronic commerce. At present, legislation on the integrity of civil activities in our country is largely embodied in contract laws, the general principles of the civil law, and other laws, and mainly in the form of basic principles. These laws lack pertinence and are not workable, and therefore not effective in punishing those who do not obey the principles of good faith and protecting those who do, especially in the special environment in online trading.

\section{B. 2.2 A transaction information asymmetry between the two parties}

Compared with the traditional way, the advantage of electronic commerce lies in its efficiency, convenience while it also has the biggest advantage that both parties can't communicate effectively. The old Chinese saying, "Sellers are always cleverer than buyers" is actually referring to the information asymmetry of the two parties. The buyer is always at an informational disadvantage, and the electronic commerce mode intensifies the information asymmetry. The buyers can only acquire the detailed product information and description through the photos offered on the electronic commerce websites, which cannot allow them to examine the quality of the products to be bought. Some electronic business enterprises and websites offer misleading product information to intentionally deceive consumers in online shopping. Even some electronic business enterprises use this feature of e-commerce to deceive consumers for a profit.

\section{Poor awareness of business integrity}

Poor quality, too much publicity, untimely delivery, and a lack of after-sale service and a series of other behaviors are caused by the drive of dishonest pursuit of economic interests of the sellers. In the transition of Chinese economy from planned economic system to market economic system, driven by economic interests, the sellers' credit consciousness is poor, resulting in a serious lack of credit. The researches of the Ministry of Commerce on enterprise credit system show that the direct and indirect economic losses incurred to the enterprises due to a lack of credit account to $¥ 585.5$ billion Yuan every year, equivalent to $37 \%$ of the annual national fiscal revenue. The business operators who are engaged in dishonest or fraudulent behaviors are at a lower risk in China. For example, if Amazon prices the products at a very low price in other countries, even as low as \$ 1 USD due to its own mistakes, it has to arrange the product delivery even if it will cause severe economic losses to the company. However, if this kind of incident does happen in our country, what the company needs to do is merely to give customers a slight comfort, rather than to earnestly fulfill their obligations. That is why it is said business operators in our country are at a lower risk of losses after credit crisis.

\section{CONSTRUCTING THE E-COMMERCE CREDIT SYSTEMS}

\section{A. Improving the e-commerce laws and regulations}

Market economy is a kind of economy that is based on credit and laws. It should be more so in the electronic commerce mode. A complete legal system on credit management is the requirement for the healthy development of the credit industry. Dishonest behaviors causing damages to others should be punished by the law. The perfection of relevant laws can regulate the behaviors of both parties in electronic commerce trade and to reduce the legal blind area, and thus resulting in the better development of the electronic commerce development. Therefore, we should constantly improve our legal system. For example, the features of electronic commerce should be fully taken into consideration to create a good legal environment and space for development for electronic commerce in formulating or revising certain laws and regulations such as the patent law, the trademark law, the copyright law, anti-unfair competition law, the contract law, the corporate law, and the law of negotiable instrument. In addition, certain electronic trading laws and systems, the electronic payment system, the credit card system should be established according to the environment of electronic commerce and its transaction characteristics. Many legal problems involved in the electronic commerce, such as the taxes and judicial jurisdiction in electronic commerce, intellectual property protection, and the protection of consumers' rights should also be settled as soon as possible.

\section{B. Building a sound credit database}

First of all, a consumer credit database should be established. At present, it is hard to make a fair credit 
evaluation because there is a general lack of personal credit materials, and even the acquired materials are highly dispersed and in high secrecy. In addition, the personal property status is not very transparent or real, so it is difficult to set unified standards. All these factors determine that all relevant state departments and electronic business bodies concerned work together to unify the consumer credit filing standards, thus effectively managing the enterprise consumer capital. The establishment of credit files for the participants in electronic commerce can reflect consumer's personal credit and transaction records in unified, standard forms.

Secondly, the electronic business enterprise credit database should also be established. Credit files should be established for the enterprises in electronic commerce after identity authentication. It should record the information about the honest operations of the enterprises, but also the information about their dishonest behaviors. The information collection for enterprise credit systems should draw on the information published regularly by authorities and departments in industry and commerce, taxation, customs, technical supervision, quality inspection (such as the basic industry and commerce registration information, and quality control, information, etc.). Meanwhile, departments concerned can make use of supervisory function of consumers to collect enterprise credit information on public, convenient, equal public information platforms.

Finally, a reliable credit evaluation system should also be established. The participating parties of the transaction have the final say of the credit of each other. Therefore, it is more meaningful to construct an evaluation system for electronic commerce participants. The participants of electronic commerce are the beneficiary as well as the leading force in evaluation system. In this system, all participants can give evaluation of the credit status of the other party. A comprehensive evaluation of the credit rate of the participants is made on the basis of qualitative and quantitative analysis of the transaction records and credit records so as to provide security for future transactions. At the same time, the construction of authoritative credit rating center should be quickened to rate the credit records of enterprises and consumers in electronic commerce, and to issue rating certificates to them to ensure the safety and reliability of electronic commerce.

\section{Strengthening self-discipline in the e-commerce industry}

At present, each e-commerce website has its own trading rules, which often make online shoppers stop, worrying about the possible infringement of their rights and interests. Self discipline is critical to the construction of electronic commerce credit environment. China electronic commerce association as China's e-commerce industry organization should make business rules that all members should abide by, and protects the rights of consumers. Ecommerce websites can't add overbearing articles in fixed contracts, nor cheat the consumers or damage the consumers' rights with traps. The association should deal with the complaints against their members through the Internet and punish those who do not abide by the business rules, or even expel them from the association. At the same time, there should be a consensus in e-commerce industry that in any industry today a company's image in the consumers' mind can be greatly improved if it has integrity. With the increasing homogeneity of the electronic commerce and consumption experience differentiation reduced, the good faith is a very important factor to improve image of electronic commerce in the consumers' minds. So more attention should be paid to that in e-commerce industry for its long-term development.

\section{CONCLUSION}

The wide application of electronic commerce in the enterprises can, to a large extent, expand trade opportunities, improve the trade efficiency, and enhance the enterprise's competitiveness and strain capacity. Therefore, the establishment of electronic commerce credit system to strengthen the inspection of the clients and the risk management before, during and after the event can not only effectively reduce the risk of enterprise management and promote enterprise's economic competitiveness, but also can facilitate the rapid development of electronic commerce in our country. The construction of the electronic commerce credit system is a complicated social system engineering, which requires both the creation of a good social credit environment, such as the improvement of the citizens' legal awareness and the citizens' concept of good faith, and the perfection of legal system, judicial system, governmental supervision, and the self-discipline within the industry. Only by the joint efforts from all the social communities, can our country's electronic commerce credit environment be effectively improved and further purified to ensure the healthy and stable development of the electronic commerce in our country to bring more benefits and provide more convenience for the society and the people.

[1] Wang Jing,and Yuan Wen-wei, "Analysis on the Current Situation of E-commerce Credit and Mechanism Construction,"Value Engineering,2012

[2] Wang Min, Ren Huan,and Zou Yang, “Analysis and Countermeasure Research on Chinese Electronic Commerce Credibility,”Technology Square,2012

[3] Wang Yue , “ Impact on the integrity of China's e-commerce thirdparty payment,”West Forum on Economy and Management,2012

[4] Alessandro Acquisti, "Privacy in Electronic Commerce and the Economics of Immediate Gratification,"European Economic Association,2008

[5] Paul Johnson, “ Honesty Integrity Trustworthiness,” 